\title{
Tackling Youth Unemployment in East-Central Europe ${ }^{*}$
}

\author{
K. Roberts, C. Fagan, K. Foti, B. Jung, S. Kovatcheva, L. Machacek ${ }^{* *}$
}

This paper draws upon evidence from survey research in Bulgaria, Hungary, Poland and Slovakia to describe how young people's old routes into the labour markets in East-Central Europe have disintegrated in the 1990s while new routes and career groups have been created. A typology of these new routes is constructed and is then used to explain how and why levels of youth unemployment have risen and refuse to fall even in countries where, according to official economic statistics, recovery is now well-advanced, and despite the introduction of active labour market measures. It is concluded that levels of youth unemployment will subside, and prevent the creation of excluded groups, only if the development of the new market economies is managed.

Diese Studie basiert auf Umfrageergebnissen aus Bulgarien, Ungarn, Polen und der Slowakei. Es wird gezeigt, wie herkömmliche Wege in den Arbeitsmarkt für junge Leute versagen und sich neue Wege und Karrieremöglichkeiten eröffnen. Es wird eine Typologie dieser neuen Wege konstruiert, mit deren Hilfe erklärt werden kann, warum die Jugendarbeitslosigkeitsrate steigt und warum sie selbst in solchen Ländern nicht fällt, in denen die wirtschaftliche Erholung fortgeschritten ist und wo drastische Maßnahmen zur Arbeitsbeschaffung unternommen werden. Es wird geschlossen, daß die Jugendarbeitslosigkeit nur dann unter Kontrolle zu bekommen ist, wenn die Entwicklung junger Marktwirtschaften erfolgreich verläuft.

* manuscript received: 10.09.98, revised: 11.11.98, accepted: 21.12.98.

The research on which this paper is based has been supported by grants from the Economic and Social Research Council (L309-25-3054), ACE/PHARE (P95-2141-R) and the UK Overseas Development Administration (R6665)

** Kenneth Roberts, born 1940, is Professor of Sociology at the University of Liverpool. During the 1990s he has co-ordinated a series of projects on young people in East-Central Europe and the former Soviet Union. Colette Fagan, born 1964 is Lecturer in Sociology at the University of Manchester. Her main research interests are gender divisions and labour markets. Klara Foti, born 1959, is a Senior Research Fellow at the Institute for World Economics of the Hungarian Academy of Sciences. She is an economist with special expertise in the transformation of East-Central European economies in the 1990s. Bohdan Jung, born 1954, is Professor and Director of the Institute of International Studies at the Warsaw School of Economics. His recent research has been into cultural production and consumption in Poland, and the impact of European integration. Siyka Kovatcheva, born 1959, is a lecturer in Sociology at the University of Plovdiv. She is a political sociologist with special interests in youth. Ladislav Machacek, born 1943, is a Senior Fellow at the Institute of Sociology at the Slovak Academy of Sciences. His research interests are in youth work and youth organisations. 


\section{Tackling youth unemployment}

High rates of youth unemployment, around 30 percent throughout East-Central Europe, are generally regarded as the region's number one youth problem. Governments in all the countries, plus international aid providers and advisers, are anxious to find solutions. But this is an instance where the real priority must be to define the problem correctly. Diagnoses which suppose that the young unemployed are the problem, and which prescribe remedies involving remedial education, basic training and stiffening their determination to find work by making unemployment benefits less attractive, more difficult to obtain or withdrawing this support altogether, are destined to fail. These remedies all suppose that the young unemployed are trapped by their lack of the right qualifications, skills, experience and/or motivation. In fact, rates of youth unemployment have risen alongside the restructuring of young people's routes into the labour market in the course of the societies' transitions from centrally planned to market economies. It is within this restructuring rather than the young people themselves that robust explanations of the levels and distribution of youth unemployment in East-Central Europe can be found. And only policies which act upon and modify the labour market opportunities awaiting young people are likely to succeed in hauling down the current youth unemployment rates.

\section{Analysing youth transitions}

One proven (in Western societies) methodology for investigating young people is to begin by recognising that youth is a process involving a number of transitions one of which, arguably the pivotal transition, is from education into employment. It is then possible to identify the main career routes that young people follow from different kinds of family backgrounds, via different forms of education and training, then into different kinds of employment, to establish which young people tend to be recruited into each of the routes, their typical experiences while in transition, and their typical destinations (see Banks et al, 1992). It is also possible to explore the inter-connections between education to employment and other youth transitions - in family relationships and residential arrangements for example - and to analyse how young people's attitudes and self-concepts develop, or prove resilient, throughout these experiences.

This methodology disaggregates young people while recognising that they all encounter specific life stage challenges, and imposes a longitudinal perspective upon any analysis. With the information assembled it is possible to identify similarities and contrasts in the experiences of different groups of young people within any country, and what are likely to be the contrasting implications of particular macro-trends and structures for such different groups. The methodology can reveal how young people's situations and responses change over time within given countries, and can also be used to compare their 
situations in different societies. This mode of analysis, therefore, can be extremely effective in examining how the transition from communism has impacted among the various socio-demographic groups of young people in the various countries of East-Central Europe and the former Soviet Union. This mode of analysis can reveal exactly why youth unemployment has risen to its current levels, and what must be done to haul these levels down. It confirms an old maxim: nothing is more practical than a good theory. This is illustrated in the following passages with evidence from studies of young people in Bulgaria, Hungary, Poland and Slovakia conducted between 1993 and 1997. Specifically, the evidence is from 1993 surveys of a total of 1800 18-24 year olds in three regions of Poland (Gdansk, Katowice and Suwalki), and a separate set of matched surveys in 1997 based on interviews with totals of 800 unemployed, and 400 self-employed under 30 year olds in Bulgaria, Hungary, Poland and Slovakia.

\section{Old career routes}

Under communism most young people progressed along highly structured routes towards employment. Relationships between education and initial training, entry jobs and longer-term occupations were extremely tight. For example, these links were stronger in the German Democatic Republic than in the Federal Republic even though the links in the latter were stronger than in most Western societies (see Konietzka and Solga, 1995). Young people from intelligentsia and other families where the parents were employed in professional or management occupations usually received a general (academic) secondary education, typically followed by higher education, which led into the same kinds of jobs as the parents held. The rewards for educational success were primarily cultural (financial advantages were less clear cut) and it was parents who valued the relevant cultural rewards who were the most anxious for their children to be academically successful. They usually ensured that their children attended good elementary schools, received such additional coaching as was necessary to pass the entrance exams set by academically selective secondary schools, and likewise at the point of entering higher education (Gerber and Hout, 1995; Mateju, 1989; Mozny, 1992; Roberts and Jung, 1995). Other young people received their secondary education in vocational or professional schools, often linked to state departments or enterprises. In these schools the young people were usually prepared for very specific types of employment which, in the normal course of events, they duly entered. The normal expectation was that these would be the individuals' long-term occupations. It was possible, sometimes necessary, for individuals to break out and switch tracks, but all the pressures from the political and economic contexts encouraged young people to accept their destinies. 
These links were evident in the careers of the representative samples of young people in three regions of Poland who were surveyed in 1993 (see Table I). Young people from elite families had usually been educated in general (academic) secondary schools, while most non-elite children went to professional or vocational schools. Irrespective of the type of secondary school attended, elite children were the most likely to proceed into higher education, though matriculation from general secondary education was the normal entry requirement. All the young people in this 1993 study had commenced their education under communism. It was not so much the existence, but the strength of the relationships between home backgrounds, types of schooling, recruitment into higher education then into elite jobs, that surprised Western observers. Positive discrimination in favour of young people from working class and peasant families was abandoned in the early years of communism, before it impeded the progress of children of the new elites.

Table I: Poland 1993: Social Origins and Education

Parental status ${ }^{1}$

\begin{tabular}{||l|c|c||}
\hline \hline Type of secondary school attended & Elite & Non-elite \\
\hline Vocational & $\%$ & $\%$ \\
\hline Professional & 9 & 36 \\
\hline Lycee & 24 & 46 \\
\hline \hline $\begin{array}{l}\text { Percentages of graduates entering } \\
\text { higher education }\end{array}$ & 67 & 20 \\
\hline Vocational schools & 38 & 1 \\
\hline Professional schools & 40 & 25 \\
\hline Lycees & 84 & 45 \\
\hline
\end{tabular}

Source: Roberts and Jung, 1995.

In the 1990s these old transitional processes have remained visible. In general it is still well-educated parents who are most likely to seek higher education for their children, and, therefore, the kinds of secondary schooling that are most likely to lead in this direction. Some young people are still proceeding along the old career routes and obtaining commensurate employment. However, the dislocation of the old command economies has broken many of the former links (see Fabian, 1991; Grunert and Lutz, 1996; Kabatek, 1990).

\footnotetext{
${ }^{1}$ Based on mothers' and fathers' education and occupations.
} 


\section{Deconstruction}

Many of the state enterprises that formerly recruited graduates from vocational and professional schools have closed or downsized, leaving the young people with no routes forward. Many of these schools have lost their former functions. Some have adapted (see Roberts and Szumlicz, 1995) but many have closed while others have transformed themselves into general secondary schools.

New career destinations have appeared - jobs in private businesses, selfemployment and unemployment, for example. Links between these destinations on the one hand, and young people's family and educational backgrounds on the other, have typically been weak or non-existent. Young people with all types and levels of education have been at risk of unemployment when there have been insufficient commensurate jobs in their localities. In Poland in 1993 young people's risks of unemployment, on completing their education and entering the local labour markets, bore no tidy relationship to their types of secondary schools and educational qualifications (see Table II).

Table II: Poland 1993: Unemployment Rates by Type of Secondary Education

\begin{tabular}{||l|l||}
\hline \hline & \% \\
\hline Lycee & 34 \\
\hline Professional school & 17 \\
\hline Vocational school & 25 \\
\hline
\end{tabular}

Source: Roberts and Jung, 1995.

Individuals with all types of specialisations - in accountancy, computing and plumbing for instance - have been able to try to work on their own accounts, and their success or failure has not depended primarily on their educational credentials. In these circumstances many young people have concluded that no types of education confer any definite career advantages any longer. Many have become uncertain as to which jobs are the more desirable. Who has the best job nowadays, a school-teacher or a hotel receptionist? Many young people experience their post-communist situations as chaotic. Parents continue to assist their children in so far as they are able to do so. Indeed, families have commonly been young people's main source of support. But the types of family background and support that are advantageous have become unclear. Some types of socio-cultural capital have been devalued (positions in the old Party hierarchies in many ex-communist countries, for example) while others (such as experience in the second economies) have been upgraded.

This has created situations in all former communist countries where the young people in the various new labour market locations have been drawn from a wide 
variety of family and educational backgrounds. Our 1997 survey of unemployed and self-employed young people in Bulgaria found that both groups were drawn from families who had occupied the same range of jobs under communism. It is true that the self-employed's parents were the more likely to have held professional or management jobs, and that the young unemployed's parents were the more likely to have experienced unemployment in the $1990 \mathrm{~s}$, but these relationships were weak. Most of the self-employed were workers' children, and less than a fifth of the young unemployed's parents were also out-of-work (see Tables III and IV). There was a much wider overlap between these career groups' social backgrounds than between the groups educated in different types of secondary schools in Poland who were surveyed in 1993.

Table III: Bulgaria 1997: Parents' Main Occupations Pre-1989

\begin{tabular}{||l|c|c||}
\hline & Unemployed youth & Self-employed youth \\
\hline & $\%$ & $\%$ \\
\hline $\begin{array}{l}\text { Management, } \\
\text { professional }\end{array}$ & 14 & 22 \\
\hline Skilled, white-collar & 38 & 41 \\
\hline Other workers & 43 & 33 \\
\hline Farm & 2 & 3 \\
\hline $\begin{array}{l}\text { Housewives, did not } \\
\text { work }\end{array}$ & 4 & 2 \\
\hline
\end{tabular}

Source: Kovatcheva, 1997.

The old career routes and groups have disintegrated in the 1990s. Alongside these trends, young people's peer group relationships and activities, and their socio-political attitudes, have ceased to map clearly onto their current labour market positions and recent experiences. This can be seen in the comparisons in Table $\mathrm{V}$ between samples of the young unemployed and the young selfemployed in Bulgaria, Hungary, Poland and Slovakia who were surveyed in 1997. The two groups were very similar in their nationalities and religious affiliations, there was a wide overlap in their types of schooling, and although there were some differences in their socio-political attitudes the self-employed and the unemployed were never poles apart. For example, overwhelming majorities of each favoured closer ties between their own countries and the European Union, and rather less overwhelming majorities were in favour of the market economy, though in both groups there was considerable nostalgia for the old way of life - more believed that family life had declined than improved in quality in the course of the reforms. 
Table IV: Bulgaria 1997: Parents' Careers Since 1989

\begin{tabular}{|c|c|c|}
\hline & Unemployed youth & Self-employed youth \\
\hline & $\%$ & $\%$ \\
\hline Same job & 42 & 33 \\
\hline \multicolumn{3}{|l|}{ Other job } \\
\hline State & 7 & 6 \\
\hline Private & 9 & 10 \\
\hline Self-employed & 6 & 27 \\
\hline Unemployed & 17 & 4 \\
\hline $\begin{array}{l}\text { Withdrawn from } \\
\text { workforce }\end{array}$ & 14 & 20 \\
\hline Deceased, other & 7 & 3 \\
\hline
\end{tabular}

Source: Kovatcheva, 1997.

The absence of clear divisions in background or ideology between such contrasting career groups as the unemployed and the self-employed has been indicative of the societies being in transition. The societal transitions are probably taking much longer than most people in East-Central Europe expected when their countries embarked upon the reforms, but 'transition' remains the preferred definition of the countries' situations. Young people who are unemployed, or who are unable to work according to their specialities and aspirations, comfort themselves with the belief that before long market reforms will bring widespread benefits and their own prospects will improve (see Kovatcheva, 1997).

\section{Reconstruction}

However, by the mid-1990s the first post-communist generations of young adults were becoming more clearly differentiated, separated from one another, as a result of settling, whether by choice or force of circumstances, in different labour market situations. For example, among the many who had tried to 'do business' some (including many in the samples of young self-employed people who we surveyed in 1997) were experiencing success and building long-term entrepreneurial careers. Meanwhile others, from among the much larger numbers with some experience of unemployment, were at risk of becoming long-term unemployed adults. The proportions becoming parts of these particular career groups have not differed greatly in terms of family and educational backgrounds, but in the post-communist labour markets they have gradually become distinct 'classes' (see Roberts et al, 1997; Roberts and Jung, 
1995). As can be seen in Table VI, many of the young self-employed in Bulgaria, Hungary, Poland and Slovakia in 1997 had some experience of unemployment, but these episodes had usually been brief. Conversely, the unemployed were, in most cases, chronically unemployed - for nearly a half of

Table V: Four East-Central European countries, 1997: Unemployed and SelfEmployed Youth

\begin{tabular}{|c|c|c|}
\hline & Unemployed & Self-employed \\
\hline & $\%$ & $\%$ \\
\hline \multicolumn{3}{|l|}{ Nationality } \\
\hline Majority & 90 & 97 \\
\hline Minority & 10 & 3 \\
\hline \multicolumn{3}{|l|}{ Religion } \\
\hline Catholic & 58 & 56 \\
\hline Protestant & 6 & 7 \\
\hline Orthodox & 20 & 21 \\
\hline Non-Christian & 3 & 2 \\
\hline None & 13 & 14 \\
\hline \multicolumn{3}{|l|}{ Highest education } \\
\hline Elementary & 17 & 1 \\
\hline Vocational & 22 & 18 \\
\hline Professional & 27 & 29 \\
\hline Lycee & 24 & 25 \\
\hline College & 5 & 6 \\
\hline University & 6 & 22 \\
\hline \multicolumn{3}{|l|}{ Views } \\
\hline $\begin{array}{l}\text { Family life: old system } \\
\text { better }\end{array}$ & 53 & 38 \\
\hline Prefer market economy & 51 & 79 \\
\hline $\begin{array}{l}\text { Wants closer ties with } \\
\text { EU }\end{array}$ & 85 & 91 \\
\hline
\end{tabular}

Source: $\quad$ Roberts et al., 1997. 


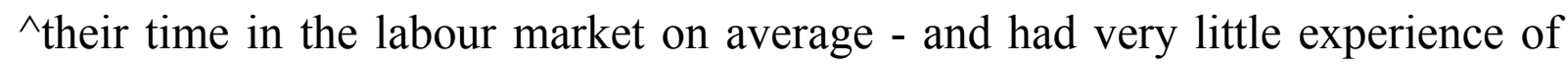
self-employment as a main economic activity (see Table VI). As early as 1993 in Poland some young people were obtaining, and retaining employment, while others were experiencing repeated failure in their efforts to establish themselves in the workforce (see Table VII).

Table VI: Four East-Central European Countries 1997: Career Experiences of Unemployed and Self-Employed Youth

\begin{tabular}{|c|c|c|}
\hline & Unemployed & Self-employed \\
\hline & $\%$ & $\%$ \\
\hline \multicolumn{3}{|l|}{ Ever been: } \\
\hline a. Unemployed & 100 & 38 \\
\hline b. Self-employed & 6 & 100 \\
\hline \multicolumn{3}{|c|}{$\begin{array}{l}\text { Percentage of career } \\
\text { spent: }\end{array}$} \\
\hline a. Unemployed & 46 & 8 \\
\hline b. Self-employed & 3 & 41 \\
\hline
\end{tabular}

Table VII: Poland 1993: Career Groups Positions at time of survey

\begin{tabular}{||l|c|c||}
\hline & Employed & Unemployed \\
\hline $\begin{array}{l}\text { Percentages of post- } \\
\text { secondary school lives } \\
\text { spent in: }\end{array}$ & $\%$ & $\%$ \\
\hline Education & 14 & 13 \\
\hline Employment & 64 & 28 \\
\hline Unemployment & 8 & 44 \\
\hline National service & 12 & 10 \\
\hline Something else & 2 & 6 \\
\hline
\end{tabular}

Source:Roberts and Jung, 1995.

It is likely, therefore, that by the time that the second post-communist generations of young people are making their transitions to adulthood, some will have been reared in successful business families, others will be from households where the parents have been more-or-less continuously employed, while others will have been reared by long-term unemployed, or intermittently unemployed, 
parents. By then the formation of new socio-economic strata, or classes, will be well-advanced. Everything that we know about stratification processes and outcomes in market economies suggests that parents who have been successful in business will ensure that their children receive a 'good' education and enjoy subsequent career advantages, partly as a result of the credentials that they earn, coupled with the families' financial circumstances and business connections. By then the children of the disadvantaged are likely to have become an excluded group. In the 1990s the young unemployed in East-Central Europe have not been a group apart in terms of their social backgrounds, lifestyles or sociopolitical orientations, but this state of affairs must be regarded as transitional.

\section{Emergent occupational strata}

The evidence from our surveys among young people in post-communist labour markets shows that five distinct career groups are in fact being created (Roberts, 1998). One is characterised by its employment in private businesses, some being Western implants or joint ventures, and others locally owned and managed. The more substantial private businesses offer rates of pay, fringe benefits and career prospects far superior to the local norms (see Hardy, 1997). Young people who are successful in obtaining such employment tend to hold on, if they can. If they choose, or are obliged, to change jobs, their experience assists them in finding similar alternatives. These jobs can be described as Westernised by virtue of the level of commitment expected of employees, and the reward levels.

The second career group is composed of young people who enter, and hold on to, public sector employment despite its overall contraction and the erosion of the former security that such jobs once offered, and the relative pay.

The third group is composed of those young people who succeed, and establish themselves as proprietors of private businesses.

The fourth group comprises those who take and retain or move between successive jobs in such small enterprises. Employment in small private businesses in East-Central Europe has all the disadvantages of similar jobs in the West, but to an even greater extent. The jobs are usually extremely insecure, the work irregular, and often wholly or partly 'in the shade', and hourly earnings are rarely much higher than in the public sector.

The fifth career group is composed of the non-employed - young people who fail to establish themselves in any form of employment.

This career group typology can be useful for comparing different postcommunist societies, and for revealing trends over time. For example, one would expect careers in Westernised employment to be most common in the countries where the transition is progressing most rapidly. In so far as the entire 
post-communist bloc is being Westernised this route should expand everywhere, gradually or rapidly. Eventually the route could become dominant, influencing terms and conditions of employment throughout the post-communist economies. In this event the entire occupational structures of the societies will be Westernised and the main strata will be composed of different kinds of occupations (as in the West) rather than jobs in different kinds of businesses.

However, it is also likely, arguably probable, that the former communist societies will never acquire systems of occupational stratification closely resembling those created earlier in the West. One would expect the postcommunist countries to exhibit 'late modernisation' effects. The new career routes and social divisions created are likely to be exceptionally responsive to late-twentieth century global conditions. Some features of the emergent patterns of socio-economic stratification in former communist countries could therefore prove prototypical rather than transitional. This could apply to the division between primary (Westernised) and secondary businesses and employment, the public-private split, and the growth of self-employment as a distinct career option for young people. In Western countries broader trends in technology and economic life are enabling some young people to create new self-employed careers, in cultural production for example, often straddling the formal and informal economies, and incorporating legal and non-legal activities (see Smith and Maughan, 1997).

\section{Youth unemployment: the problem redefined}

Career route analysis can be used to explain why youth unemployment has risen to its current levels across East-Central Europe, and why the levels remain so stubbornly high even in the face of economic growth and net job generation, despite more young people extending their full-time education, and despite all the 'active measures' that have been introduced. Equally useful, the typology can identify the conditions that will have to be fulfilled for youth unemployment to subside. The creation of long-term non-employed strata could be another prototypical feature of the post-communist countries, but the creation and perpetuation of such a group is not inevitable. This future can be averted, but only if, to begin with, the problem is diagnosed correctly.

Youth unemployment has risen throughout East-Central Europe alongside cutbacks in public sector employment, and a steep decline in the attractiveness of the public sector jobs that remain. The jobs have been stripped of their former security, and have suffered a decline in their status and pay relative to what has been on offer in parts of the private sector. Westernised employment has a high profile but remains chronically scarce, and is concentrated in EastCentral Europe's capital cities. Most new job creation has been by small, locally owned and managed enterprises. Some of the proprietors have done extremely well but as yet very few can be described as quality employers. Actual pay per 
hour may be marginally ahead of public sector rates but the private sector jobs are even less secure if only because so many of the businesses themselves are marginal. A great deal of the employment is casual, or with fluctuating hours depending on the work flow. Much employment in this sector is 'grey' and working conditions are often poor.

The evidence presented earlier has shown that most of East-Central Europe's present-day young unemployed have parents who held decent, though not necessarily high status, jobs under communism. The detailed evidence to corroborate the following points is presented elsewhere (see Roberts et al, 1997), but it should surprise no-one that it shows that most young people in East-Central Europe, including most of the young unemployed, expect jobs at least as good, better really, than their parents'. The parents rarely expect them to aim or settle for less. The vast majority of the young unemployed in EastCentral Europe are decently educated, have specialities, and believe that they have earned the right to commensurate employment. They do not believe that an outcome of the reforms should be that they spend their lifetimes in menial jobs.

In the meantime they prefer to remain 'in transition'. This is how they view their own situations. This view is facilitated by the willingness of parents to support grown-up children. This was common under communism when many young couples continued to reside with one set of parents for many years after marrying and having children of their own. Remaining in transition is often made financially bearable by working spasmodically, or more regularly, in EastCentral Europe's buoyant second economies. Enrolment in part-time (usually paid for) education helps many unemployed young people to feel that their careers are in fact progressing. And all this is over-arched by a belief that the countries themselves are in transition. So young people do not feel compelled to abandon their original aims (usually to work in their specialities) and lower their sights. They believe that before long the situations in their countries will improve and make their own aspirations realisable.

State labour market policies and programmes are too weak to make a significant impact. Young people dismiss unemployment benefits as 'pitiful' - far less than many are able to earn 'in the shade'. The withdrawal of unemployment benefit is not a 'big stick'. Nor are the Labour Offices' active programmes attractive 'carrots'. These consist mainly of temporary jobs with very modest pay, and education and training usually pitched at levels beneath the young unemployed's existing skill levels and qualifications. Moreover, most of the measures are perceived as dead ends. The Labour Offices throughout East-Central Europe are trapped in a downward spiral - avoided by workers seeking quality jobs and employers seeking quality labour.

East-Central Europe's youth unemployment is a massive problem but it is not an immediate crisis. Most of the young people are in fact remaining in transition. They have not lost touch with the labour market. They remain socially 
integrated, and the overwhelming majority continue to support 'the reforms'. Few are becoming long-term welfare dependents, criminal outlaws or fodder for anti-democratic political movements. East-Central Europe has 10-15 years to avert this nightmare scenario, but unless in the meantime levels of unemployment are hauled down, the countries will become divided into beneficiaries (of the reforms) and excluded groups.

The 'holy grail' is not a quick fix but policies that are guaranteed to work in the medium term. This will mean expanding Westernised employment, reversing the degradation of public sector employment, and developing more small businesses into medium-sized quality firms that are able to offer quality jobs. It is not obvious that East-Central Europe is already firmly on course. There are still no countries where most people are better off than they were under communism. Given the trends of the 1990s, 'all other things remaining equal' will turn the aftermath of communism into the late-twentieth century's great deformation. A pre-condition for avoiding this future is to cease looking for quick fixes, to cease treating the young unemployed themselves as the problem, and to concentrate, over the next 10-15 years, on expanding the new career routes that have already been upgraded while gradually upgrading others.

\section{References}

M Banks, I Bates, G Breakwell, J Bynner, N Emler, L Jamieson and K Roberts (1992), Careers and Identities, Open University Press, Milton Keynes.

D Fabian (1991), 'Programmes of unemployed youth participation', in L Machacek, ed, Youth and State, CSFR 1991, Slovak Academy of Sciences, Bratislava.

T P Gerber and M Hout (1995), 'Educational stratification in Russia during the Soviet period', American Journal of Sociology, 101, 611-660.

H Grunert and B Lutz (1996), 'A double process of destabilisation in post-socialist societies: the case of Germany', paper presented to workshop of the European Science Foundation Scientific Network on Transitions in Youth, La Ciotat.

J Hardy (1997), 'Cathedrals in the desert? Transnationals, corporate strategy and locality in Wroclaw', paper presented to Regional Studies Association conference, Regional Frontiers, Frankfurt-Oder.

A Kabatek (1990), 'The youth - a social factor in revolutionary changes in Czechoslovakia', in L Machacek, ed, Sociology of Youth, CSFR, Slovak Academy of Sciences, Bratislava.

D Konietzka and H Solga (1995), 'Two certified societies? The regulation of entry in the labour market in East and West Germany', paper presented to workshop on Transitions in Youth: Comparisons Over Time and Across Countries, Oostvoorne.

S Kovatcheva (1997), 'Restructuring age relations in East-Central Europe', paper presented to European Sociological Association Conference, Essex. 
P Mateju (1989), 'Family effect on educational attainment in Czechoslovakia, Netherlands and Hungary', in J L Peschar, ed, Social Reproduction in Eastern and Western Europe, Department of Sociology, University of Groningen.

I Mozny (1992), 'The Czech family in transition: from social to economic capital', paper presented at conference on Social Responses to Political and Economic Transformation in East-Central Europe, Central European University, Prague.

K Roberts (1998), 'Understanding school-to-work transitions in former communist countries', British Journal of Education and Work, forthcoming.

K Roberts, C Fagan, K Foti, B Jung, S Kovatcheva and L Machacek (1997), 'Youth unemployment in East-Central Europe', Sociologia, Slovak Sociological Review, 29, 671-684.

K Roberts and B Jung (1995), Poland's First Post-Communist Generation, Avebury, Aldershot.

K Roberts and T Szumlicz (1995), 'Education and school-to-work transitions in postcommunist Poland', British Journal of Education and Work, 8, 54-74.

R Smith and T Maughan (1997), Youth Culture and the Making of the Post-Fordist Economy: Dance Music in Contemporary Britain, Discussion Paper 97/2, Royal Holloway College, London. 